Author: MJ Maluleke

CULTURE, TRADITION, CUSTOM, LAW AND GENDER EQUALITY

2012 VOLUME 15 No 1

http://dx.doi.org/10.4314/pelj.v15i1.1 


\section{CULTURE, TRADITION, CUSTOM, LAW AND GENDER EQUALITY}

\section{MJ Maluleke*}

Culture is like an umbrella under which some people like to hide from rain, and also to shade themselves from the sun. But sometimes you need to fold it.

\section{Introduction}

Traditional cultural practices reflect the values and beliefs held by members of a community for periods often spanning generations. Every social grouping in the world has specific traditional cultural practices and beliefs, some of which are beneficial to all members, while others have become harmful to a specific group, such as women. These harmful traditional practices include early and forced marriages (Ukuthwala as practised currently), virginity testing, widow's rituals, 'u ku ngena' (levirate and sororate unions ${ }^{1}$ ), female genital mutilation ${ }^{2}$ (FGM), breast sweeping/ironing, the primogeniture rule, practices such as 'cleansing' after male circumcision, and witch-hunting.

Despite their harmful nature and their violation of national and international human rights laws, such practices persist because they are not questioned or challenged and therefore take on an aura of morality in the eyes of those practising them.

Mikateko Joyce Maluleke. Advocate of the High Court; Director in the Gender Directorate; Department of Justice and Constitutional Development (Republic of South Africa). Presentation delivered at the Conference of the South African Chapter of the International Association of Women Judges (SAC-IAWJ) in partnership with the North-West University (Potchefstroom Campus), Faculty of Law, Potchefstroom; LexisNexis; Juta and Do: Gender Directorate entitled "Equal access to Education and Training for Women: Pathway to Decent work for Women", on 12-13 August 2011 at Potchefstroom, South Africa.

** Ramphela "Speech".

1 Levirate unions occur when the deceased's surviving male relative inherits the widow of the deceased. Sororate unions occur where the widower is inherited by the deceased wife's surviving female relative. The inherited widow or widower becomes the wife or husband to the surviving relative of the deceased.

2 FGM is not just the cutting of the clitoris; it includes disfigurement, and the changing of the form or elongation of the labia as practiced by Tsonga and Sotho communities. 
The purpose of this article is to discuss the impact of culture, ${ }^{3}$ tradition $^{4}$ custom ${ }^{5}$ and law on gender equality. However, before the article discusses that matter it will examine the influence of colonialism ${ }^{6}$, imperialism ${ }^{7}$ and apartheid on the African culture, traditions and customs with particular reference to South African culture, traditions and customs. This will include a brief review at what really constitutes African culture, tradition and custom, and what is a colonial or imperial construct which is now regarded as African culture, tradition and custom. It will be argued that the primogeniture rule ${ }^{8}$ is not an original African cultural principle but a colonial and imperial construct. In our dialogue about the revival of our culture, tradition and customs we need to interrogate what is African and what is a colonial or imperial construct.

The presentation will demonstrate that law reform and development have traditionally focused on reforming state legal institutions to the exclusion of customary legal systems, and that where the courts had an opportunity to develop the customary legal systems they either reinforced archaic customary laws or imposed western ideology. It will show that pre-colonial and pre-apartheid African culture, traditions and customs were based on Ubuntu. It will conclude by showing that harmful traditional practices, as outlined previously, are a violation of women's human rights as guaranteed in the Constitution, perpetuate the inequalities between women and men, and contribute to the extreme poverty that government is trying to eradicate.

3 Culture is a combination of the ideas, customs and social behaviour of a particular people or society (Weiner and Simpson Oxford English Dictionary).

4 Tradition is the transmission of customs or beliefs from generation to generation; it is a long established custom or belief that has passed from one generation to another (Weiner and Simpson Oxford English Dictionary).

5 Custom is a traditional and widely accepted way of behaving or doing something that is specific to a particular society, place or time; it is things done habitually (Weiner and Simpson Oxford English Dictionary).

6 Colonialism is the establishment, maintenance, acquisition and expansion of colonies in one territory by people from another territory (Wikipedia [date unknown]a en.wikipedia.org).

7 Imperialism means creating an empire, expanding into the neighbouring regions and expanding dominance. Its origins date back to the Romans. It involves political and economic domination of the other (DifferenceBetween.net [date unknown] www.differencebetween.net). Imperialism takes the form of political control and creating economic dependence.

8 The primogeniture rule is the right, by law or custom, of a firstborn to inherit the entire estate, to the exclusion of younger siblings (Wikipedia [date unknown]c en.wikipedia.org). 


\title{
2 Background
}

African culture has experienced rapid change since the colonial invasion. Contemporary African culture is a mixture of traditional elements and alien features. Local African culture was oppressed for many years by white South Africans, who find their cultural roots in western countries. Western cultures tend to be more individualistic and focused on individual achievements and personal interests, whereas African cultures are collectivistic, group-oriented, and concerned with the welfare of their community.

Native law was officially recognised in 1848, but only insofar as it did not infringe on the humanitarian principles of 'civilised society' - understood to be 'white society' in that day. ${ }^{9}$ The aim was to maintain control over African people. The strategy adopted was to manipulate the way of life through the codification of customary law, as seen from the eyes of the colonisers. Many research reports and scholarly writings have revealed that customary law and its practices have been tampered with. Writers such as Prof Chanock and others argue that:

\begin{abstract}
Although there is the view that colonialists 'invented' customary law as a way to govern natives while under the auspices of paying tribute to their culture and heritage, some other writers have argued that customary law was not so much 'invented' by them, but 'manipulated' so as to conform the actual practices of the natives to their westernized ideals as part of their 'civilizing mission'. These writers prefer to view the colonial influence more as 'imagination', rather than 'invention'. ${ }^{10}$
\end{abstract}

However, due to the living nature of customary law, there is one African principle that colonialism and imperialism could not manipulate, i.e. Ubuntu. All Africans, particularly indigenous Africans, will tell you that our parents always taught us about Ubuntu. (It is not clear whether current parents are passing on the baton or not). Ubuntu means, 'I am what I am because of who we all are'. Ubuntu underscores the importance of agreement or consensus. 
The overall concept of Ubuntu values people as a community, rather than as individuals. The Zulus and other peoples have a saying, 'umuntu ngumuntu ngabantu', which means a person is a person through other persons. It is a humanistic way of life which holds ethics and morals at the forefront of everything. All African cultural, traditional and customary practices, including those pertaining to women and children, were based on Ubuntu. The following section will look at the international and national legal framework regarding cultural, traditional and customary practices, and gender equality.

\section{The international legal framework and the South African Constitution}

South Africa is a member of the international community, and since the advent of democracy has ratified, signed or acceded to many treaties, including the Convention on the Elimination of all Forms of Discrimination Against Women (CEDAW) which was ratified by South Africa in 1996 without a single reservation. ${ }^{11}$ Given that South Africa also ratified the Optional Protocol on CEDAW, which strengthened existing enforcement mechanisms, South Africa has committed itself to be bound by the provisions of CEDAW and its Optional Protocol. ${ }^{12}$

Article 2 defines discrimination and includes violence against women as a form of discrimination. Article 16 of CEDAW requires state parties to take all appropriate measures to eliminate discrimination against women in all matters relating to marriage and family relations. It further obliges state parties to ensure that 'the betrothal and the marriage of a child shall have no legal effect and all necessary actions, including legislation, shall be taken to specify a minimum age for marriage, and to make the registration of marriages compulsory'.

The Protocol to the African Charter on Human and Peoples' Rights on the Rights of Women (Protocol to the African Charter), ${ }^{13}$ article 2(1)(b) provides that state parties must enact and effectively implement appropriate legislative or regulatory measures,

\footnotetext{
11 South Africa ratified the CEDAW in 1996 and presented its first Country Report in 1998. Country reports on the CEDAW are available on UN DAW [date unknown] www.un.org.

12 The Optional Protocol was signed by South Africa on 18 October 2005 and came into force on 18 January 2006.

13 The Protocol to the African Charter was adopted in 2003 and came into force on 25 November 2005 when it received its $15^{\text {th }}$ ratification.
} 
including those prohibiting and curbing all forms of discrimination, particularly those harmful practices which endanger the health and general wellbeing of women. It also contains important provisions on reproductive rights, marriage, divorce and inheritance rights, among others.

In addition to the international commitments, the South African Constitution enshrines the rights of all people in South Africa and affirms the democratic values of human dignity, equality and freedom (section 7 of the Constitution), declares its supremacy (sections 1(c) and 2 of the Constitution), and provides that any law or conduct inconsistent with it is invalid. ${ }^{14}$ The right to equality, including gender equality, is one of the fundamental pillars of the Constitution, and it is enshrined in the Bill of Rights, which is justiciable.

On the other hand, the Constitution also provides for and protects the right to culture (sections 15(3), 30 and 31 of the Constitution) and recognises traditional leadership (sections 211, 212 of the Constitution), which recognition could be interpreted as protecting polygamy as well as related practices such as 'spouse inheritance', ${ }^{15}$ $U_{k u t h w a l a^{16}}$ and other customary practices which have the impact of undermining the constitutional guarantee of gender equality. ${ }^{17}$ However, the provisions protecting the right to culture explicitly include a qualification stipulating that 'no one exercising these rights may do so in a manner inconsistent with any provision of the Bill of Rights' (sections 30, 31(2) of the Constitution). But what does this mean in practice for a young girl in the rural areas who has to endure many harmful practices in the name of her culture?

14 The Constitutional Court has reiterated the supremacy of the principle of equality in the face of indigenous law that discriminated against women in several decisions. See Gumede $v$ President of the Republic of South Africa 20093 BCLR 243 (CC); Bhe $v$ The Magistrate of Khayelitsha 20051 SA 580 (CC).

15 This will be briefly discussed in par 4.4 below. See 'Consent to a customary marriage'

16 The practice of Ukuthwala will be briefly discussed in par 4.4 below. See 'Consent to a customary marriage'. For a detailed discussion of this customary practice see Koyana and Bekker 2007 De Jure 139-144.

17 Section 9 of the Constitution explicitly acknowledges the intersectionality of different grounds of discrimination as prohibited. The Promotion of Equality and Prevention of Unfair Discrimination Act 4 of 2000 (Equality Act) recognises patriarchy and discrimination on the grounds of sex and gender as being of such a prevalent and serious nature that it specifically singles out these forms of discrimination for special treatment. In addition to outlawing unfair discrimination, the Equality Act contains provisions which encourage both the public and private sectors to create a nonsexist society. 
Customary practices such as Ukuthwala, virginity testing, widow's rituals, and others are entrenched, and in practice take precedence over equality in the villages where they are carried out. It is therefore questionable whether the constitutional protection of gender equality is making a difference to women living in communities with a strong commitment to traditional norms and practices. These compromises on women's right to equality can thus be interpreted to mean that women, as opposed to men, do not have inherent rights.

In order to support this argument, the following section of this paper explores the impact of the following harmful traditional practices: female genital mutilation (FGM), early and forced marriages (Ukuthwala as practiced currently), virginity testing, widows' rituals, 'u ku ngena' (levirate and sororate unions), breast sweeping/ironing, the primogeniture rule, and practices such as cleansing after male circumcision, witch-hunting, and other practices that impinge on gender equality.

\subsection{The Children's Act 38 of 2005}

Section 12 of the Children's Act: Social, Cultural and Religious Practices specifically prohibits female genital mutilation and the circumcision of female children. Contravention of this prohibition is an offence which may result in a sentence of a fine or imprisonment of up to 10 years if found guilty.

The Children's Act also protects the privacy, bodily integrity and dignity of children, especially female children, by prohibiting virginity testing with regard to children younger than 16 years of age. Virginity testing may be practiced in relation to children older than 16 , on condition that the testing is performed in the prescribed manner and that written consent is given.

\subsection{The Promotion of Equality and Prevention of Unfair Discrimination Act, 2000 (PEPUDA)}

The definition of discrimination in PEPUDA was taken as it is from the CEDAW definition of discrimination. Chapter 2 of the Act deals with the prevention, prohibition and elimination of unfair discrimination, hate speech and harassment on any of the 
prohibited grounds, as set out in the definition of 'prohibited grounds' (which is not a closed list, but all of the 17 prohibited grounds are contained in the Constitution).

Section 8 of PEPUDA provides that the following constitute unfair discrimination:

- Section 8 (a) gender-based violence,

- Section 8(b) female genital mutilation, and

- Section $8(\mathrm{~d})$ any practice including traditional, customary, or religious practice which impairs the dignity of women and undermines equality between women and men, including the undermining of the dignity and wellbeing of the girl child.

This means that all practices such as virginity testing, Ukuthwala and others that are dehumanising young girls are regarded as unfair discrimination by PEPUDA. The rights in PEPUDA can be enforced in the courts; there are specialised courts called Equality Courts where the violation of all these rights can be reported.

\subsection{The Criminal Law (Sexual Offences and Related Matters) Amendment Act 32 of 2007 (Sexual Offences Act)}

Having sex with a child without her consent following her kidnapping and abduction (Ukuthwala) constitutes rape in violation of the Sexual Offences Act (section 15). Regarding a child, the age of consent is 16 ; meaning that sex with an under-16 constitutes a sexual offence. Sex with a child that is 12 or below is rape, as a child of that age is legally incapable of consent. The Act also prohibits other sexual activities with children (sections 16 and 17), including sexual grooming (section 18).

Section 17 of the Sexual Offences Act prohibits the sexual exploitation of children by their parents and others. Parents, relatives or others who collude in, or aid and abet, the Ukuthwala of a girl child commit the crime of the sexual exploitation of children. These parents and relatives also face being charged with Trafficking in Persons, under section 71 of the Sexual Offences Act. 


\subsection{The Recognition of Customary Marriages Act 120 of 1998 (RCMA)}

According to the Recognition of Customary Marriages Act, both the bride and the bridegroom must consent to a marriage. The age of consent is 18 years of age.

\subsection{The Prevention and Combating of Trafficking in Persons Bill [B7-2010] (the Bill)}

The Bill prohibits the recruitment, sale, supply, procurement, transportation, transfer, harbouring, disposal or receipt of persons by means of the use of threat, force, intimidation or other forms of coercion; or by abusing vulnerability, for the purpose of exploitation. Parents, relatives and others who hand over a child into a forced marriage for financial or any other type of gain can be prosecuted under section 4 read with section 1 of the Bill.

\subsection{The Transkei Penal Code 9 of 1983}

Ukuthwala of young girls was also prohibited in Transkei under the Transkei Penal Code. The Penal Code criminalised the abduction and kidnapping of children under 18 years.

\subsection{The Domestic Violence Act 116 of 1998}

A victim of Ukuthwala may apply for a protection order under the Domestic Violence Act against family members involved in her abduction.

\section{Cultural, traditional and customary practices which are harmful to women and children}

The revival of traditions, culture and customs, and the practices derived from them, after the demise of colonialism, imperialism and apartheid will definitely require us to enter into a dialogue on the character of our ancestors and what is really indigenous. However, the process should take the context into consideration. Some of the cultural practices that were necessary then are unnecessary now due to 
development, globalisation and other factors. Some cultural practices that need to be scrutinised are discussed below.

\subsection{Virginity testing}

Virginity testing is practised mostly in KwaZulu Natal and the Eastern Cape. ${ }^{18}$ Virginity testing is the practice and process of inspecting the genitalia of girls and women to determine if they are sexually chaste. It is based on the false assumption that a woman's hymen can be torn only as a result of sexual intercourse..$^{19}$ It is a very controversial practice, both because of its implications for the girls tested and because it is not necessarily accurate.

There are two schools of thought with regards to virginity testing. ${ }^{20}$ One school of thought submits that it is a form of sex education and it enforces abstinence from sexual activities before marriage. ${ }^{21}$ Girls are taught not to allow boys or men to take away their pride by having sexual intercourse with them before marriage. It is believed that young women will abstain from sex because they fear being discovered to be no longer virgins (the implication of this fear is what the writer has a problem with). This is a stigma not only for the girl but for her entire family. It is believed that virginity testing substantially reduces the spread of sexually transmitted diseases, including HIV/AIDS, and further, that it reduces teenage and unplanned pregnancies that lead to school dropouts.

The other school of thought (to which the writer ascribes) holds that the intention of the practice of virginity testing might be good, but its flip side is gender bias. It does not treat boy and girl children equally. There are implications for gender equality and human rights as provided for in the Constitution. ${ }^{22}$ The practice also appears to threaten and objectify girl children so that fathers may get full lobola or bohali on

\footnotetext{
18 Reports from the KwaZulu Natal Rural Women's Movement and other NGOs in the Eastern Cape.

19 The use of tampons can break the hymen.

20 CGE Report on Virginity Testing 11.

21 CGE Report on Virginity Testing 11.

22 The provisions protecting the right to culture explicitly include a qualification stipulating that 'no one exercising these rights may do so in a manner inconsistent with any provision of the Bill of Rights' (ss 30, 31(2) Constitution of the Republic of South Africa, 1996).
} 
marriage. This school of thought argues that the practice of virginity testing puts the whole responsibility for safe sex, abstinence, and countering the spread of sexually transmitted diseases solely on the shoulders of girls and young women, who are often the victims of gender violence and gender inequality in so many other respects.

Women are expected to maintain a very high level of morality to be married to 'honourable' men who might have deflowered and/or impregnated a string of girl victims, and might possibly even be HIV positive. On the other hand, virginity testing poses a threat of discrimination against girl children who are not virgins (who in many instances may have been raped). The reasons advanced for virginity testing do not focus on prevention and protection.

\section{$4.2 \quad$ Ukuthwala}

Ukuthwala is a form of abduction that involves the kidnapping of a girl or a young woman by a man and his friends or peers with the intention of compelling the girl or young woman's family to endorse marriage negotiations. In ancient Africa Ukuthwala was a condoned, albeit abnormal, path to marriage targeted at certain women of marriageable age. It did not involve raping or having consensual sex with the girl until the marriage requirements had been met.

Ukuthwala was not performed, however, with impunity; it incurred delictual liability for the culprit in the form of the payment of a herd of cattle to the father or legal guardian of the girl. Today Ukuthwala involves the kidnapping, rape and forced marriage of minor girls by grown men old enough to be their grandfathers. It contradicts the reasons advanced for practicing virginity testing.

Ukuthwala retards childhood development processes.

- It burdens the girl child with the responsibility of being a wife with a husband and in most instances children and in-laws to serve or look after. 
- It is a health hazard, with problems ranging from HIV and other STIs to pregnancy-related complications such as infant and maternal mortality and fistula-related diseases. ${ }^{23}$

- The social development of the child is stunted as the early marriage and fasttracking into the adult world skips organic developmental phases. The abducted child is removed from school, and dropping out of school deprives the child of education opportunities, including tertiary education and skills training.

- Early marriage is a symptom of and exacerbates gender inequality. The subordinate position of the girl or young woman is reinforced by the fact that in most of the documented cases the girl children have been forced to marry men old enough to be their parents or grand parents.

- Community development depends on its people; this includes the level of health, knowledge and education, skills and resources controlled by those people. Since Ukuthwala undermines the girl-child's access to these resources it indirectly undermines community development.

- There is a proven link between a lack of education, underdevelopment and poverty. Ukuthwala deprives girl children of opportunities to educate and develop themselves. Furthermore, research indicates that the majority of the girls and young women that are victims of Ukuthwala are from poor families. Their lack of education and underdevelopment, due to Ukuthwala, deepens their poverty and perpetuates the cycle of poverty. In many instances the children born into poverty also tend to be poor. This contributes to the cycle of poverty in the communities, particularly rural communities, where Ukuthwala is rife.

\subsection{Ukungena}

In terms of the Recognition of Customary Marriages Act 120 of 1998 (RCMA), a customary marriage must be negotiated and entered into in accordance with customary law. Customary marriages include polygamous practices. Polygamy

23 These health complications are consistent with the findings of the UN Secretary General's Report on Violence Against Children (2006) and the findings of UN agencies such as WHO, UNICEF and UNIFEM in countries that are bedevilled by forced and early marriages. 
includes levirate and sororate unions, although the RCMA is silent about this. As it has been a cultural practice, it is still practised by some communities. If the inheriting of the deceased's spouse is conducted according to the custom of that community, and the widower or widow and the deceased spouse's relatives consent, then that marriage is a valid marriage under the RCMA.

At the International Alliance of Women's $35^{\text {th }}$ Congress held in South Africa in December 2010, women from KwaZulu Natal and the Eastern Cape reported that widows are forced to marry the brother or any male relative of the deceased husband. The widow is required to choose a husband without knowing who she is choosing because she is given a few sticks to choose from, and the stick she chooses will determine who the husband is.

If she refuses to marry one of the men selected, she is banished from her home, and she loses custody and all her inheritance. The consent might therefore be coerced or unduly influenced by family members or the community. If the woman agrees to marry the male relative due to a fear of violence, then the marriage is not valid. But what are the implications for the woman of invalidating the marriage?

\subsection{Male circumcision rituals or practices that affect women}

Civil society organisations in the Eastern Cape, KwaZulu Natal and Limpopo have been complaining about the ritual of the 'cleansing' of young men who have just completed their circumcision process. The 'cleansing' involves the young men finding a female, perhaps even a widow, and gang raping her to 'cleanse' themselves after this ritual. This is definitely not rooted in Ubuntu. It is a criminal act.

\subsection{Widows' rituals}

Widowhood is a clearly defined social role for women, that is associated with prescribed institutionalised cultural and religious norms and the concomitant social sanctions if a deviation from the defined social role occurs. However, an altogether 
different set of norms applies to men upon the death of their wives. ${ }^{24}$ The Commission on Gender Equality (CGE) conducted an in-depth country-wide study on the experiences of widowhood in different cultures and in different geographic areas in South Africa. The study revealed the following:

- There is large-scale discrimination against widows and widowers, including the imposition of burdens, obligations or disadvantages, and the with-holding of benefits, opportunities or advantages, as well as the regular harassment of widows and widowers in the context of the household, community, state and market-place.

- A woman's status shifts drastically (downward) after the death of her husband in contrast to the widower's status which remains unchanged (including in terms of the administration of the estate).

- A decrease in social status not only has implications for women's livelihood, economic status and quality of life, but also increases their vulnerability to discrimination, abuse, harassment and gender-based violence, as well as their ability to assert ther rights.

- Both women and men experience increased social pressure during widow(er)hood, but in opposite directions: widows are pressured to remain 'loyal' and 'faithful' to their late husbands, and honour their memory, whereas men are often pressured into a quick remarriage, regardless of their readiness or wish to remarry.

- If widows remarry, they rarely do so of their own free will. In some communities widows may be forced into new conjugal relations with a male relative or be forbidden to remarry, even if they wish to do so.

\subsection{Witch-hunting violence against women}

In his presentation at the CGE Conference, the then Premier of Limpopo, Adv Ngwako Ramahlodi, said that the notion of witchcraft is itself not a new phenomenon in African culture. One would venture to suggest that it is indeed a phenomenon amongst many nations of the world. In our situation our culture recognises witchcraft

24 CGE Report on Widowhood. 
as one of its main ingredients. ${ }^{25}$ Thus, for many families, when spring arrives a traditional healer is brought in to strengthen the kraal and all those who dwell in it against any harmful spirits, including those wilfully engineered by witches. The problem with this practice is that it involves violence when one is branded a witch. Most of those blamed for witchcraft are elderly people and women. This practice is rife in Limpopo, and now lately in Eastern Cape and KwaZulu Natal.

Witchcraft violence against women has been a global problem since time immemorial. It was practised in Europe, as described by William Shakespeare in Macbeth. Recently, in 2001 I was in Aarhus, Denmark, and I was invited to the annual celebration of their witches' day. They make a bonfire and burn the dummy figure of a woman on the fire.

I asked my host the following questions:

Question: Why is it a woman who is burned?

Answer: It is women who are witches.

Question: How do you identify and verify that someone is a witch?

Answer: You tie her to a stone and immerse her in the river, and if she dies, she was a witch.

In Ubuntu, old age or grey hair is a sign of wisdom and old people were respected, not abused, discriminated against or burned to death. The main ethical values of Ubuntu are respect for others, including women and children, helpfulness, community, sharing, caring, trust and unselfishness. Morals such as compassion, cooperation and communalism are highly valued and the wellbeing of the whole community is a unified objective.

The patriarchal nature of our societies, as influenced by colonialism and imperialism, explains why elderly women are targeted during witch-hunting. They are weak, defenceless and therefore easy targets. It is criminal, and the perpetrators must face the full wrath of the law.

25 CGE Report on Witchcraft Violence 1. 


\subsection{Female genital mutilation (FGM)}

Female genital mutilation (FGM) is disfigurement that includes cutting of the clitoris. It also includes changing the form of the labia or elongating them, as practiced by Tsonga and Sotho communities. In some societies FGM marks an important rite of passage into womanhood, while others believe it guarantees virginity, curbs female sexual desires, maintains hygiene, prevents promiscuity and increases fertility. ${ }^{26}$

Whatever the reasons for practicing FGM, the consequences are a health hazard. The practice is normally performed without anaesthesia, using unhygienic methods and instruments. Its consequences include sickness or death due to infection, haemorrhage, blood poisoning. ${ }^{27}$ This is torture, and the prohibition against torture is contained in s 12(1)(b) of the Constitution, and article 5 of the African Charter on Human and Peoples' Rights.

\subsection{Primogeniture rule}

The primogeniture rule, ${ }^{28}$ which has just been abolished by the Constitutional Court in the case of Bhe ${ }^{29}$ was not a customary law principle but a colonial and imperial construct imposed on Africans. The irony of it is that African males embraced it as their customary principle because it benefitted them; therefore they are the ones who were fighting against its being declared unconstitutional. The primogeniture rule was conceived by the framers of the Natal Code to be one of the main pillars of the 'native law' to their own benefit. It was imposed on Africans in order for the state to be able to litigate against one person rather than to have to join the whole family when the head of the house died. ${ }^{30}$

The African traditional culture has an almost infinite capacity for the pursuit of consensus and reconciliation, as opposed to being individualistic and competitive. Further, in terms of African culture, there are no orphans because a child is a child of

CGE Training Manual 11.

CGE Training Manual 11.

The Primogeniture Rule is the right, by law or custom, of a firstborn to inherit the entire estate, to the exclusion of younger siblings.

29 Bhe $v$ The Magistrate of Khayelitsha 20051 SA 580 (CC).

30 Chanock Law, Custom and Social Order. 
a community in which the child lived. Decision making in the African culture (as expressed in terms of the principle of Ubuntu) is by consensus - productivity is optimised, not maximised, as the case may be in other cultures. Rewards are shared and so is suffering, as opposed to the context of an individualistic culture, where rewards are given according to individual merit and suffering is viewed as a penalty for one's carelessness. Sustainable competitive advantage comes from loyalty to group goals in terms of Ubuntu.

The writer argues that the previous generations were wise and innovative and evolved with the times, and that customary law also evolved in line with the way of life and enlightenment at that time. The case of Mazibuko $v$ Mazibuko ${ }^{31}$ is proof that African customary laws, practices and the way of life have evolved.

This case involved a suit between two brothers of the deceased; the eldest brother and the deceased's twin brother. The family had given the estate of the deceased twin brother to the surviving twin because they believed that twins are one person. The custom had evolved from the practice of killing one twin to recognising that they are two people as one, and that both can live.

The eldest brother contested that view and won the case at the Natives Commission and at the Natives Appeal Commission. The Native Commissioner's judgment held that the 'custom' of twin succession did not have sufficient longevity to overcome the Code's fundamental principle of primogeniture, since it originated only within the last 50 or so years, while the law of primogeniture had been observed by natives from time immemorial.

The writer agrees with $\mathrm{McClendon}^{32}$ when he argues that the Mazibuko case shows that most of the African participants in 1929 had a very different conception of custom and customary law from that of colonial officials. Rather than something fixed and immutable, they were satisfied that although one practice had been followed 'in

\footnotetext{
31 Mazibuko v Mazibuko Natal Archives, 1 EST 2/1/2/1, Case 60/1929 quoted by McClendon 1997 Journal of Legal Pluralism.

32 McClendon 1997 Journal of Legal Pluralism 134
} 
the old days', another might be followed now, depending on the context and circumstances.

\section{Conclusion}

The danger of these harmful traditional practices is that children and adolescents whose rights to personal safety and wellbeing are violated are at increased risk of long-life developmental challenges, HIV infections, and other physical, emotional and social problems. These outcomes compromise national and international development goals, including, among others, the $\mathrm{MDG}^{33}$ goal 1: 'Eradicate Extreme Poverty and Hunger,' and goal 2, which provides for 'Achieving Universal Primary Education' in order to establish 'A World Fit for Children'. The goals on reducing child mortality and improving maternal health are also affected.

The revival of tradition, culture and customs is part of the new national and international identity; however, this revival must be rooted in a way of life based on human rights, democracy and equality for all, and understood from a point of view of Ubuntu. Thus, culture, tradition and customs have to be balanced within the social and legal context of the constitution and provisions of the Bill of Rights.

33 Millennium Declaration and Millennium Development Goals (2000). 


\section{Bibliography}

CGE Report on Virginity Testing

Commission of Gender Equality Report on Consultative Conference on Virginity Testing; 12-14 June 2000 (The Commission Johannesburg 2000)

CGE Report on Widowhood

Commission on Gender Equality Report on Widowhood (The Commission Johannesburg [date unknown])

CGE Report on Witchcraft Violence

Commission on Gender Equality Report on the National Conference on Witchcraft Violence, 6-10 September 1998 (The Commission Johannesburg 1998)

CGE Training Manual

Commission on Gender Equality Training Manual on Culture, Tradition and Religion, Gender and the Equality Act (The Commission Johannesburg [date unknown])

Chanock Law, Custom and Social Order

Chanock M Law, Custom and Social Order: the Colonial Experience in Malawi and Zambia (Cambridge University Press Cambridge 1985)

Koyana and Bekker 2007 De Jure

Koyana DS and Bekker JC "The Indomitable Ukuthwala Custom" 2007 De Jure 139-144

McClendon 1997 Journal of Legal Pluralism

McClendon TV "A Dangerous Doctrine? Twins, Ethnography, and Inheritance in Colonial Africa" 1997 Journal of Legal Pluralism 121-140 
Ramphela "Speech"

Ramphela M "Speech" (Unpublished speech delivered at the National Conference on Witchcraft Violence Thohoyandou Venda 6-10 September 1998)

UN Secretary General Report on Violence Against Children

United Nations Secretary General Report on Violence Against Children (UN Geneva 2006)

Weiner and Simpson Oxford English Dictionary

Weiner ESC and Simpson JE Oxford English Dictionary $2^{\text {nd }}$ ed (Oxford University Press Oxford 2004)

\section{Register of legislation}

Children's Act 38 of 2005

Constitution of the Republic of South Africa, 1996

Criminal Law (Sexual Offences and Related Matters) Amendment Act (Sexual Offences Act) 32 of 2007

Domestic Violence Act 116 of 1998

Prevention and Combating of Trafficking in Persons Bill [B7-2010]

Promotion of Equality and Prevention of Unfair Discrimination Act (PEPUDA) 4 of 2000

Recognition of Customary Marriages Act (RCMA) 120 of 1998

Transkei Penal Code Act 9 of 1983

\section{Register of international instruments}

African Charter on Human and Peoples' Rights (1981)

Convention on the Elimination of all Forms of Discrimination Against Women (CEDAW) (1979)

Millennium Declaration and Millennium Development Goals (2000)

Optional Protocol on the Convention on the Elimination of all Forms of Discrimination Against Women (1999) 
Protocol to the African Charter on Human and Peoples' Rights on the Rights of Women (Protocol to the African Charter) (2003)

\section{Register of case law}

Bhe $v$ The Magistrate of Khayelitsha 20051 SA 580 (CC)

Gumede v President of the Republic of South Africa 20093 BCLR 243 (CC)

Mazibuko v Mazibuko Natal Archives, 1 EST 2/1/2/1, Case 60/1929

\section{Register of Internet sources}

DifferenceBetween.net [date unknown] www.differencebetween.net

DifferenceBetween.net [date unknown] Difference Between Colionialism and Imperialism http://www.differencebetween.net/miscellaneous/difference-between -colonialism-and-imperialism/ [date of use 5 August 2011]

UN DAW [date unknown] www.un.org

United Nations Division for the Advancement of Women [date unknown] Country Reports on the CEDAW http://www.un.org/womenwatch/daw/cedaw/reports.htm [date of use 5 April 2011]

Wikipedia [date unknown] aen.wikipedia.org

Wikipedia [date unknown] Colonialism http://en.wikipedia.org/wiki/Colonialism [date of use 5 August 2011]

Wikipedia [date unknown]b en.wikipedia.org

Wikipedia [date unknown] Customary law in South Africa http://en.wikipedia.org/wiki/Cusomary_Law_in_South_Africa [date of use 5 August 2011]

Wikipedia [date unknown] cen.wikipedia.org

Wikipedia [date unknown] Primogeniture http://en.wikipedia.org/wiki/Primogeniture [date of use 5 August 2011] 


\section{List of abbreviations}

CEDAW Convention on the Elimination of all Forms of Discrimination Against Women

CGE Commission on Gender Equality

FGM Female genital mutilation

MDG Millennium Development Goals

UN United Nations

UN DAW United Nations Division for the Advancement of Women 